\title{
CONCEPTUAL DESIGN FOR A WASTE-MANAGEMENT SYSTEM THAT USES MULTIPURPOSE CANISTERS
}

The U.S. Department of Energy is evaluating the use of multipurpose canisters in the system being developed for the management and disposal of spent fuel from commercial nuclear reactors. As shown in Figure 1, this system will consist of a transportation system, a facility for monitored retrievable storage (MRS), and a repository for permanent disposal. The repository will also accept high-level waste, but multipurpose canisters will be used only for commercial spent fuel.

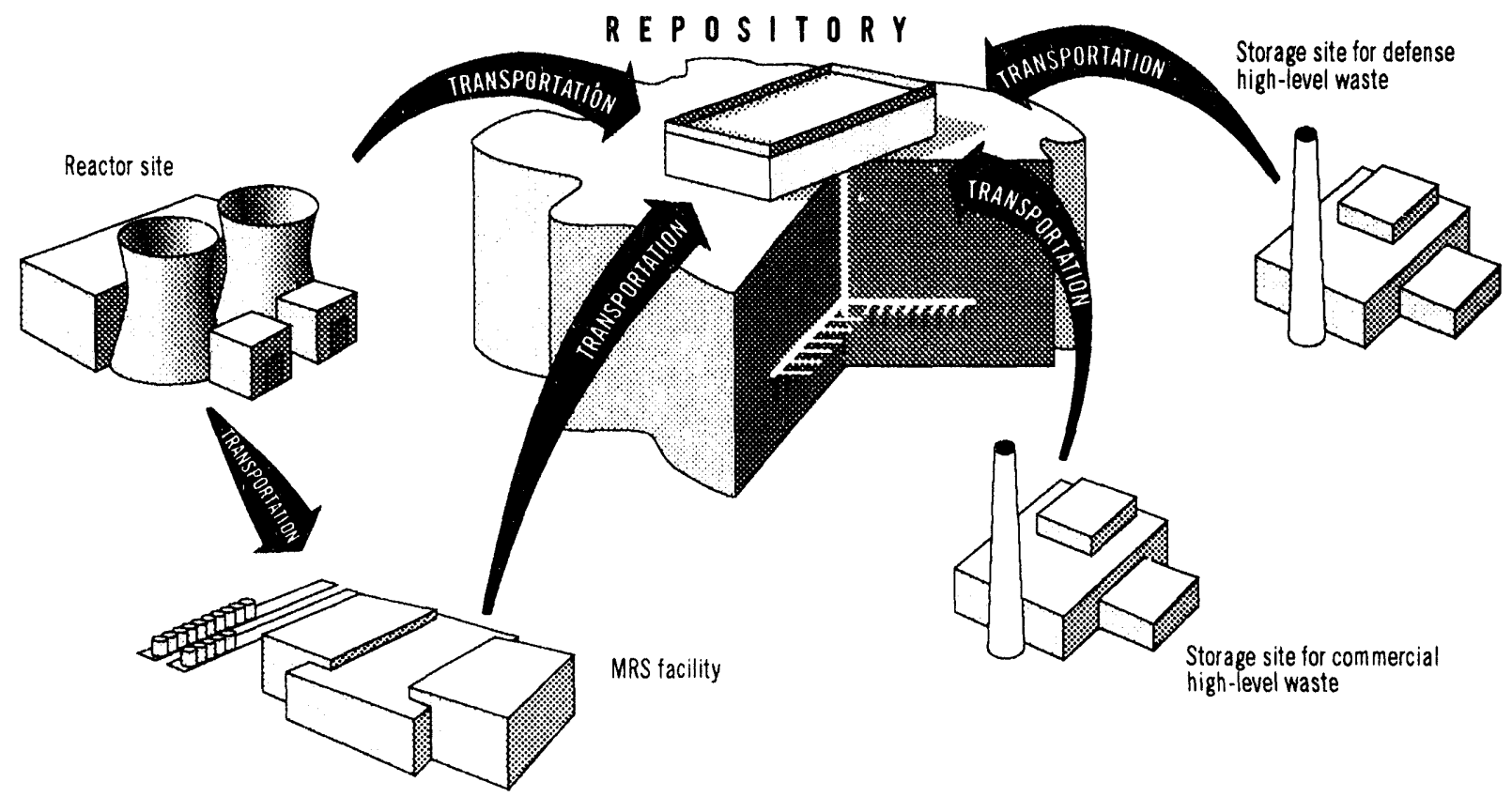

Figure 1. The waste-management system being developed by the Department of Energy. Multipurpose canisters would be used at reactor sites, at the MRS facility, and in the repository.

Spent-fuel assemblies are metal rods filled with uranium pellets. Most spent fuel is stored under water, in specially designed pools, at the site of the reactor. At many commercial reactor sites, however, the storage capacities of the pools have been exhausted, and the utilities are procuring dry-storage systems from various vendors. Several dry-storage systems are available: concrete casks, metal casks, modular vertical vaults, and modular horizontal vaults.

To provide a basis for the decision about using multipurpose canisters, the Department of Energy has recently completed a conceptual design. The work accomplished to date is described in a multivolume report. Volume I summarizes the results of the program; Volume II presents conceptual designs for the 
various components of the multipurpose canister system; Volume III contains a draft request for proposais and design specifications; and Volume IV gives cost and schedule estimates. The final volume, Volume V, contains the results of supporting studies on (1) the concept of operations, (2) operational throughput, (3) issues related to dry at-reactor storage, (4) alternative casks or canisters, (5) considerations related to the repository, and (6) regulatory consi 'erations.

\section{THE USES AND PURPOSE OF MULTIPURPOSE CANISTERS}

A multipurpose canister is a metal container holding spent fuel (Figure 2). Together with appropriate outer containers, or overpacks, it would be used for temporary storage at reactor sites, transportation from reactor sites to the MRS facility, temporary storage at the MRS facility, transportation to the repository, and disposal in the repository.

As shown in Figure 3, a different overpack would be used for each function: for transportation, the overpack is a massive, steel-walled transportation cask; for storage, either at reactor sites or at an MRS facility, the overpack is a concrete cask. For permanent disposal, the multipurpose canister would be encapsulated in another metal cask-the disposal container.

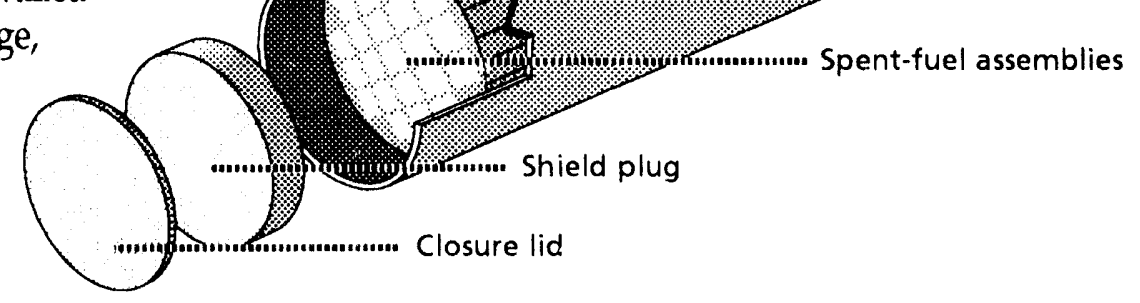
The multipurpose canister will be designed to provide (1) dry storage at reasonable cost, (2) high strength and subcriticality for transportation, and (3) acceptable internal (fuel cladding) temperatures for disposal.

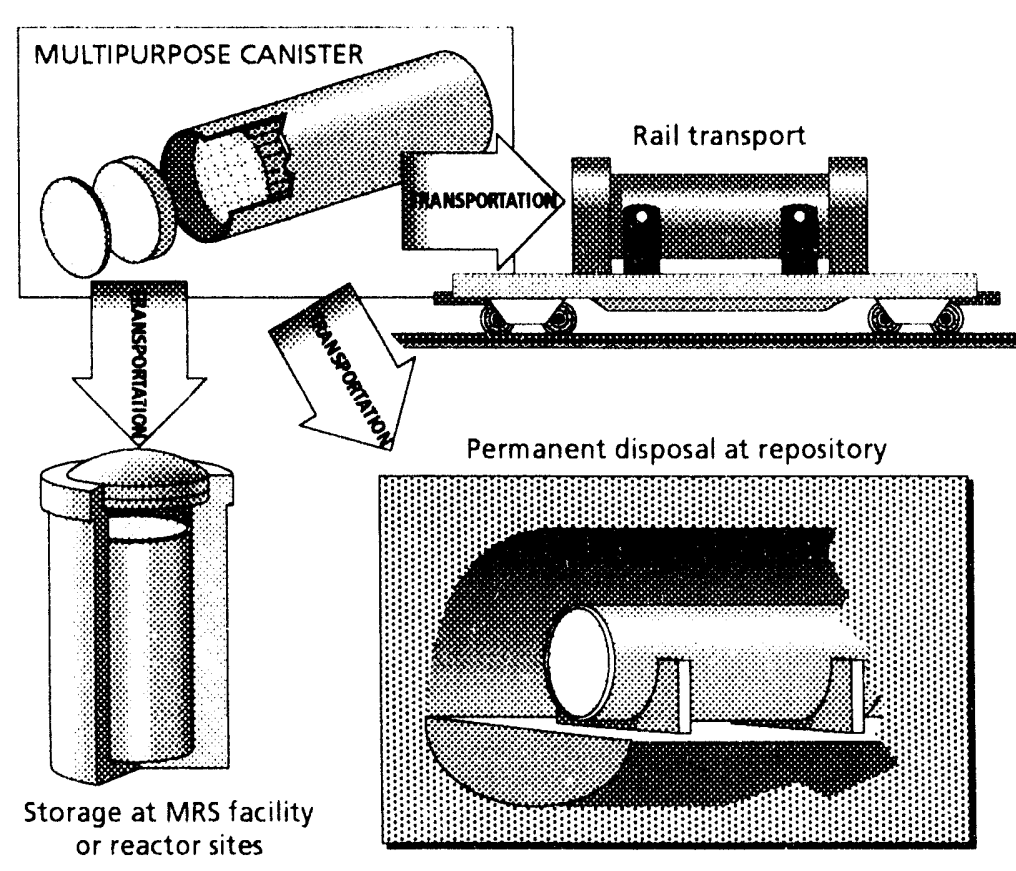

Figure 3. Proposed uses for the multipurpose canister.
The multipurpose canister offers various advantages to the management of spent fuel. Among these advaritages, two stand out. First, and most important, it minimizes the handling of spent fuel. Second, it ensures compatibility between the dry-storage devices used at reactor sites and in the Department of Energy facilities. Once loaded with spent fuel, the multipurpose canister can be welded shut and need not be reopened. If the canister concept is not used, some storage systems selected by utilities may require additional handling before shipment off the site.

If the multipurpose canister is so useful, then why was it not considered until now? 
Actually, the multipurpose canister is not a new idea. It is related to the concept of a universal cask or universal waste package - a massive metal cask, which, once loaded with spent fuel, would be used for storage, transportation, and disposal. Proposals for such a cask have been made since the late 1970s, but they were deemed impractical because of uncertainties with regard to the design of the disposal package. Recently the idea of the universal cask was reintroduced as a concept for the "robust waste package." Even more closely related is a concept considered in planning for the MRS facility: a dual-purpose cask designed for both storage and transportation. The multipurpose-canister concept combines the advantages of the universal cask and the dual-purpose cask with a practical approach.

\section{CONCEPT OF OPERATIONS}

\section{Sizing of multipurpose canisters}

To get the greatest benefit from their use, multipurpose canisters should accommodate the maximum number of spent-fuel assemblies. However, the number of assemblies that can be loaded into a multipurpose canister is limited by three factors: (1) the facilities and equipment (cranes) available at the reactor sites, (2) access to a railroad, and (3) the heat loading of the repository. An analysis of these constraints led to the present choice of two sizes for the multipurpose canisters:

1. A large multipurpose canister with a capacity of 21 assemblies from a pressurized-water reactor or 40 assemblies from a boiling-water reactor. Fully loaded and with a transportation cask, this multipurpose canister would weigh a nominal 125 tons.

2. A medium multipurpose canister with a capacity of 12 assemblies from a pressurized-water reactor or 24 assemblies from a boiling-water reactor and weighing a nominal 75 tons with a transportation cask.

Of the 121 facilities at which spent fuel is stored, 88 would be able to use the 125-ton multipurpose canister, and 14 would use the 75-ton canister. The remaining 19 facilities are not equipped for using multipurpose canisters and, unless a spent fuel assembly cask-to-cask transfer system is developed and licensed, would ship uncanistered spent fuel to the MRS facility in truck casks.

\section{Storage at reactor sites}

An empty multipurpose canister will be placed in an on-site transfer device (step 1 in Figure 4). The gap between the canister and the transfer device will be filled with deionized water and sealed with a temporary seal to prevent pool water from coming in contact with the clean outer surface of the canister. The trar:sfer devire will then be iuwered into the pool, a spent-fuel assembly will be lifted out of its storage rack and lowered into the multipurpose canister, and this step will be repeated until all the fuel slots in the canister have been filled.

In the next step, the shield plug will be set in place and the transfer device will be lifted clear of the water. The inner lid will be set on top of the shieid plug, a closure weld will be made, and the weld will be examined. A steel spacer will be set on top of this, the outer lid will be placed on top of it, and another closure weld will be made and examined. The canister will be vacuum dried and filled witii an inert gas, access ports will be sealed, and the seal and deionized water will be removed from the gap between the transfer device and the canister. After its lid has been bolted on, the transfer device vill! be decontaminated and placed in a transporter that will move it to the at-reactor storage facility, where the multipurpose canister will be transferred to a concrete storage cask (Figure 5). 


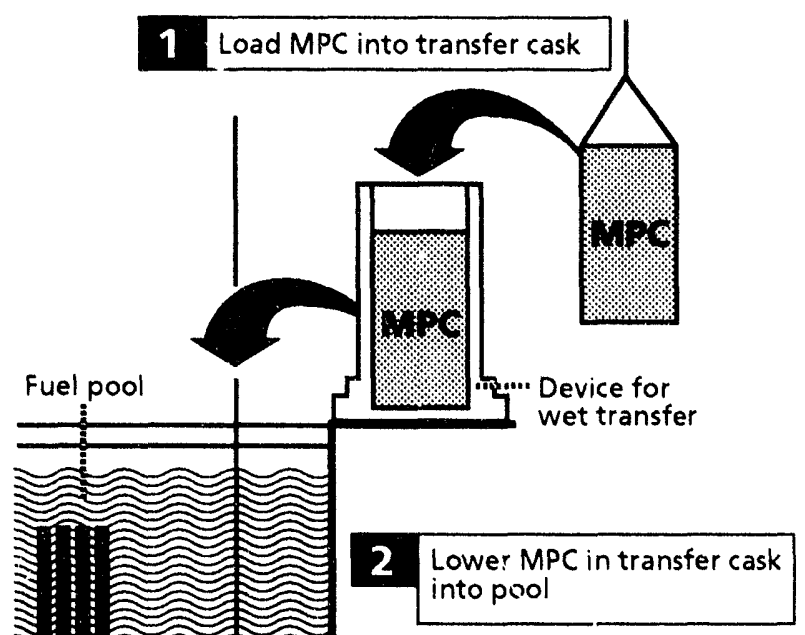

3 Load spent fuel into MPC
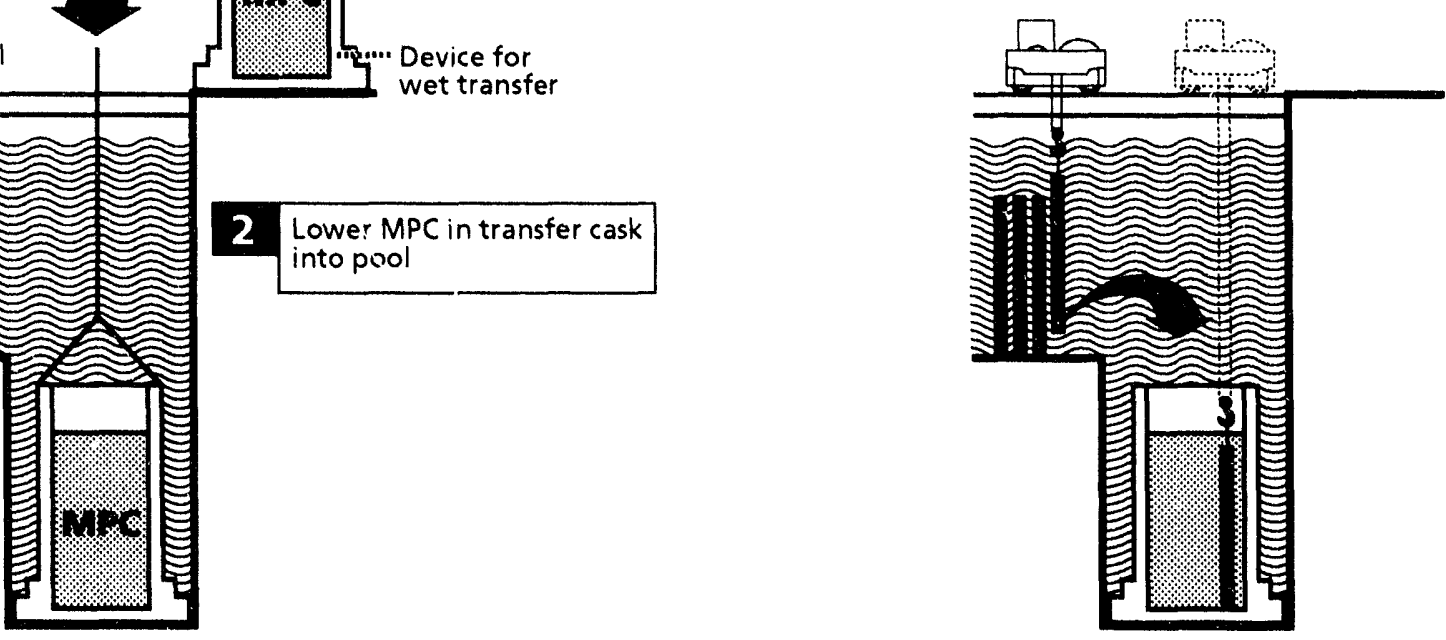

4 Place MPC shield plug

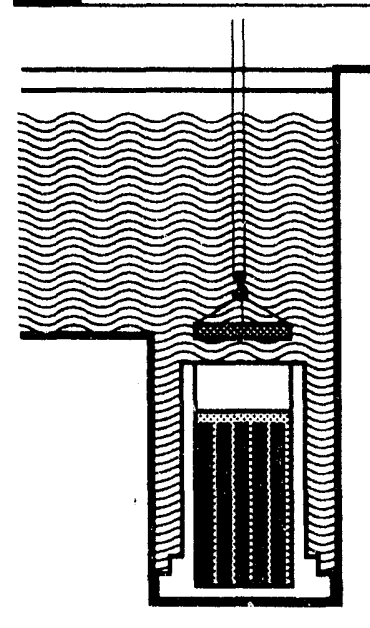

5. Weld inner lid to shield plug

- Drain, dry, inert MPC

- Weld MPC outer lid
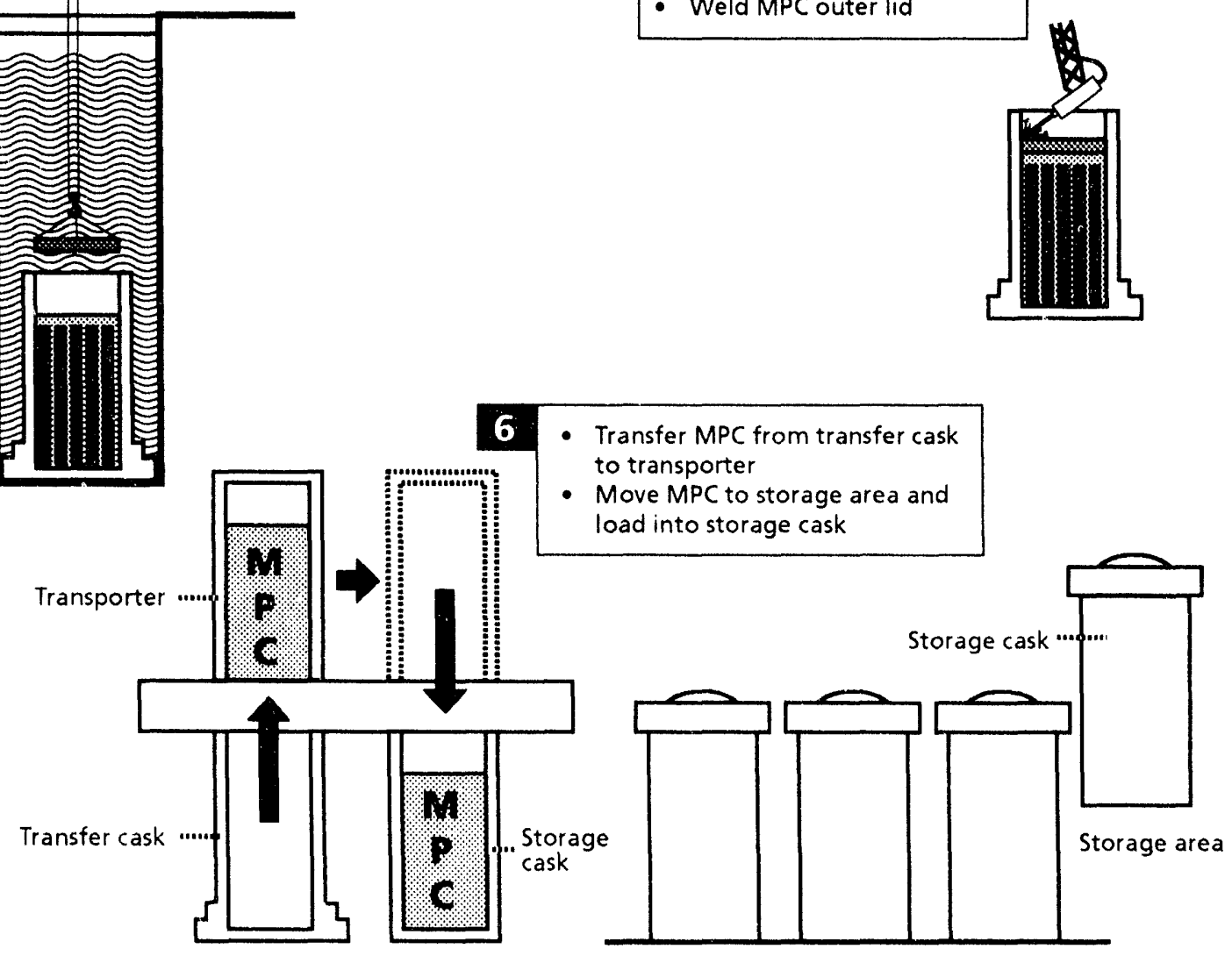

Figure 4. Steps involved in using a multipurpose canister (MPC) at a reactor site. 


\section{Transportation to the MRS facility}

When the MRS facility, described below, is ready, spent fuel in multipurpose canisters will be shipped to it by rail from the reactor sites. Loading into transportation casks will be similar to the process described above for at-reactor storage, except that in most cases a transportation cask, instead of a transfer device, will be used (Figure 6). However, of the 88 facilities using the 125-ton canisters, 32 have cranes with insufficient capacity. For these, an on-site transfer device will be used to transfer the multipurpose canister into a transportation cask.

For facilities with rail access to the building housing the spent-fuel pool, the loaded transportation cask will be placed directly on a rail car. At 22 sites, heavy-haul vehicles will be used to move the loaded transportation casks to a

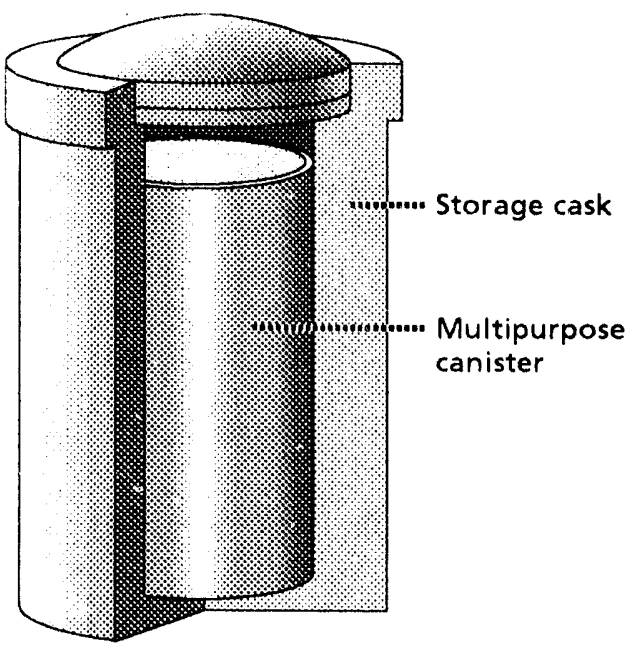

Figure 5. Cutaway view of a concrete storage cask. railhead at the site boundary. At nine sites, heavy-haul vehicles will move the casks to an off-site railhead. And in 18 cases, heavy-haul vehicles will move the transportation casks to barges for transport to a railhead.

If no spent fuel assembly cask-to-cask transfer system is available, the 19 facilities that cannot handle multipurpose canisters will ship uncanistered spent fuel by truck in 25-ton transportation casks.

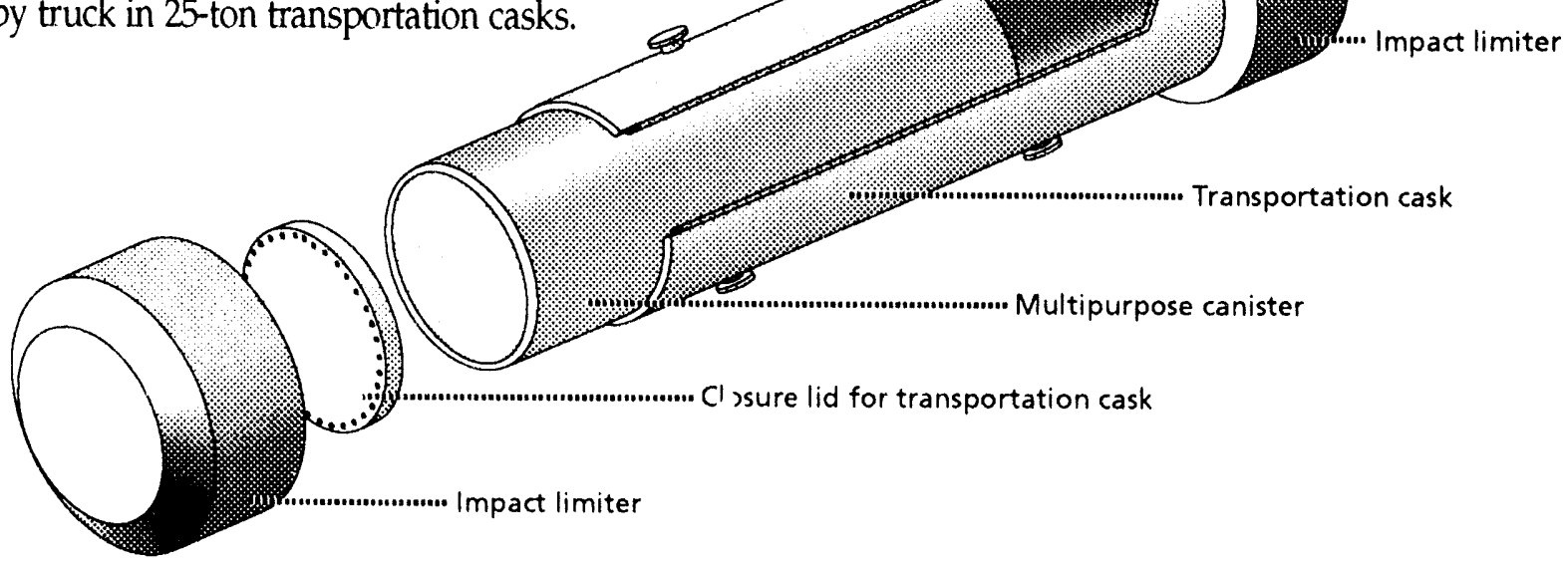

Figure 6. Transportation cask carrying a multipurpose canister.

\section{Operations at the MRS facility}

In the multipurpose-canister system, the MRS facility will accept spent-fuel shipments from reactor sites, load the assemblies shipped by truck into multipurpose canisters, and provide temporary storage for a limited amount of spent fuel. When a repository is ready, workers at the MRS facility will retrieve the loaded multipurpose canisters from storage and ship them to the repository. Spent fuel will continue to come to the MRS facility from reactor sites, and shipments will go out to the repository. The MRS facility will provide monitoring, management, and maintenance for the stored canisters. It will also house a maintenance facility in which empty transportation casks will be inspected and loaded with empty multipurpose canisters for shipment to reactor sites. 
The MRS facility will include a large paved storage yard, a waste-handing building with a transfer cell and dual-capability transfer room, and various support structures. Several modes of dry storage could be used, but the concept chosen for detailed evaluation in the conceptual design report is the vertical concrete cask, much like the cask assumed to be used for dry storage at reactor sites (Figure 5).

When a loaded canister arrives at the MRS facility, it will be placed either in storage or on a dedicated train for shipment to the repository. A multipurpose canister going into storage will be transferred from the transportation cask to a concrete storage cask inside a transfer room used only for multipurpose canisters. A lid will be placed on the storage cask, and a special transporter (Figure 7) will move the cask to the storage yard.

Incoming transportation casks carrying individual fuel assemblies will be unloaded inside a dedicated transfer cell. Here the spent-fuel assemblies will be loaded into multipurpose canisters. During the loading operation, the canister will be either inside a storage cask or a transportation cask, depending on whether the fuel will stay at the MRS facility or be shipped to the repository.

When the canister is retrieved from storage for shipment to the repository, the concrete storage rask will be transported back to the transfer room, where the canister will be loaded into a rail transportation cask.

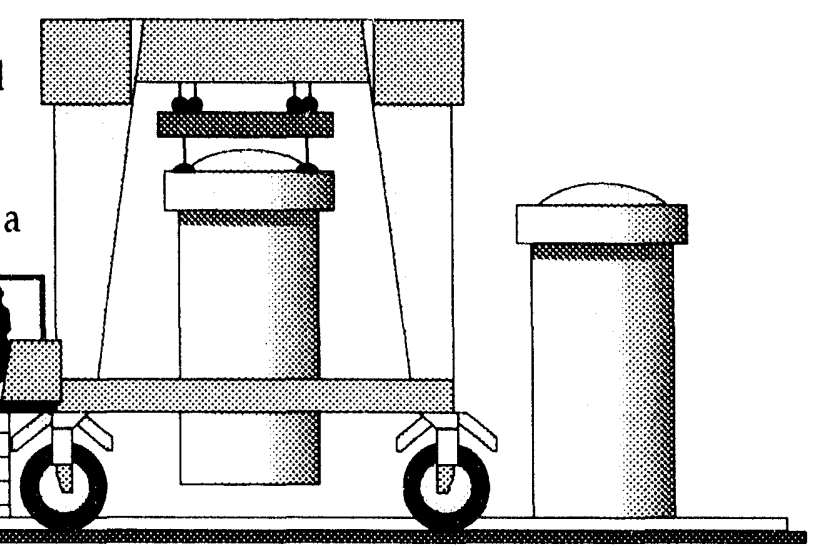

Figure 7. Transporter used at the MRS facility to move a loaded storage cask to the storage yard.

\section{Operations at the repository}

At the repository, the loaded transportation cask will be received in the waste-handling building at the surface. Here the multipurpose canister will be unloaded from the transportation cask and transferred into a disposal overpack (Figure 8), which will be sealed by welding. A shielded transporter will be used to move this waste package - the canister inside the disposal overpack - down the ramp to the underground repository and the designated disposal room. In the disposal room, the waste package will be placed on the floor.

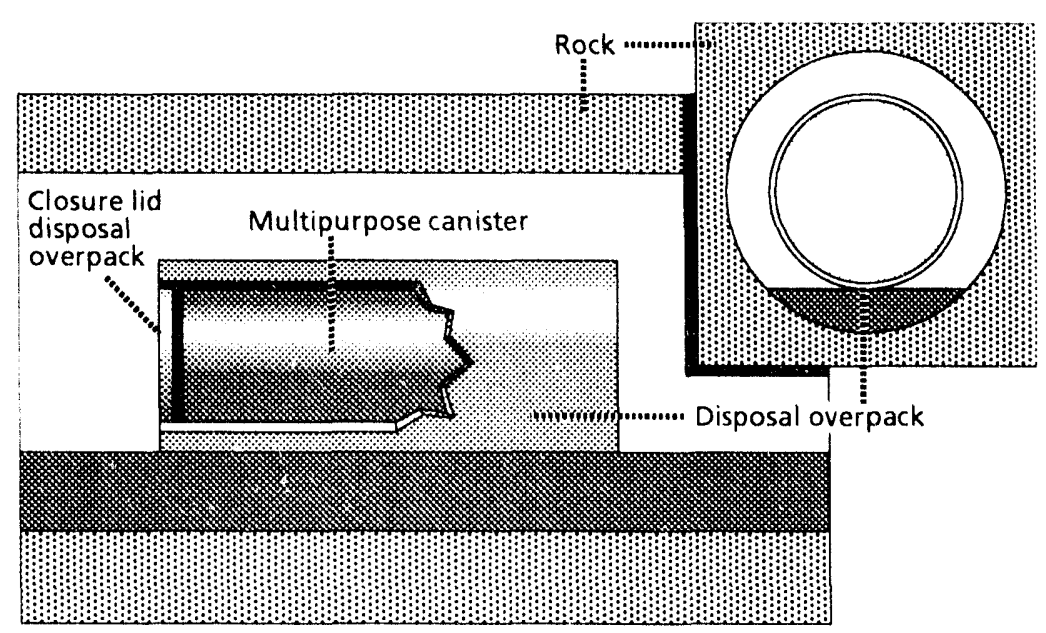

Figure 8. Cutaway view of a waste package emplaced on the floor of an underground disposal room. 


\section{CONCEPTUAL DESIGNS}

Conceptual designs have been developed for the multipurpose canisters, the transportation casks, and the MRS facility. Design concepts were also considered for transfer facilities that will be needed at reactor sites.

Four concepts corresponding to utility system constraints were identified. However, the systems necessary to fulfill the transfer functions are specific to each reactor site, as they depend on specific constraints, the storage mode, and the design of the dry-storage facility, if any. For this reason, actual designs for utility transfer systems were not developed for the conceptual design report. No specific design was developed for the disposal overpack to be used at the repository; this design must await further data from site characterization. However, for the purpose of cost estimating, it was assumed that the disposal overpack would be made of a thin inner layer of Alloy 825, an Inconel steel, to provide corrosion resistance and a thicker outer layer of low-carbon steel to provide radiation protection and a corrosion allowance.

All of the conceptual designs were based on the requirements identified for the overall wastemanagement system as well as the pertinent system component - storage or transportation. Satisfying regulatory requirements and ensuring safety were the overriding objectives in each case.

\section{Multipurpose canister designs}

The multipurpose canisters must be designed to provide storage at reasonable cost, high strength, control of nuclear criticality, radiation shielding, and efficiency in transportation. Although disposal requirements for the multipurpose canisters have not been fully defined, some constraints have been identified. Among them is the requirement for long-term criticality control. The conceptual designs provide these features and meet all other requirements for dry storage and transportation. The intent was to use existing technology and to license the canisters under 10 CFR Part 72 for storage and 10 CFR Part 71 for transportation.

\section{Dimensions and weights}

Four canister configurations were developed for the conceptual design:

1. A large canister with a maximum capacity of 21 pressurized-water-reactor assemblies.

2. A large canister with a maximum capacity of 40 boiling-water-reactor assemblies.

3. A medium canister with a maximum capacity of 12 pressurized-water-reactor assemblies.

4. A medium canister with a maximum capacity of 24 boiling-water-reactor assemblies.

In the case of the large multipurpose canister for 21 pressurized-water-reactor assemblies, it will be necessary to obtain, from the Nuclear Regulatory Commission, credit for the burnup of spent fuel in order to receive a license for this design. (Burnup indicates the degree to which fissile material in the spent fuel has been depleted in the reactor.) No credit for burnup will be needed for the other canister designs.

Both of the large canisters are designed for reactor-site cranes with a capacity of more than 100 tons. They have an "under-the-hook" weight limit of 125 tons; that is, in order for the canister to be directly loaded into a transportation cask in the reactor's spent-fuel pool, the combined weight of the following components must not exceed 125 tons: the canister without its outer lid, the spent fuel, water, the transportation cask without its lid, and the lifting yoke. For the medium canisters, a 75-ton limit similarly applies. 
In developing the conceptual designs, the Department of Energy used a balanced and conservative approach that attempts to maximize the capacity of the canister within the size and weight constraints of transportation casks.

\section{Components}

A multipurpose canister consists of a cylindrical shell with two lids, a basket to contain spent-fuel assemblies, and a shield plug (see Figure 2). The basket provides structural support for the spent-fuel assemblies and is a conduit for the transfer of heat generated by the fuel. It is also designed to prevent the spent fuel from reaching a "critical" configuration under all credible transportation-accident scenarios.

A cross section of a multipurpose canister and its fuel basket is shown in Figure 9.

The shell provides structural support for the fuel basket and maintains the stability of its configuration. Together with the inner lid, the shell provides during storage a primary containment boundary that prevents the release of radioactive material. The outer lid provides secondary containment; it also serves as the redundant seal that meets the storage requirements for containment under the regulations of the Nuclear Regulatory Commission (10 CFR Part 72). No credit is taken for multipurpose-canister containment

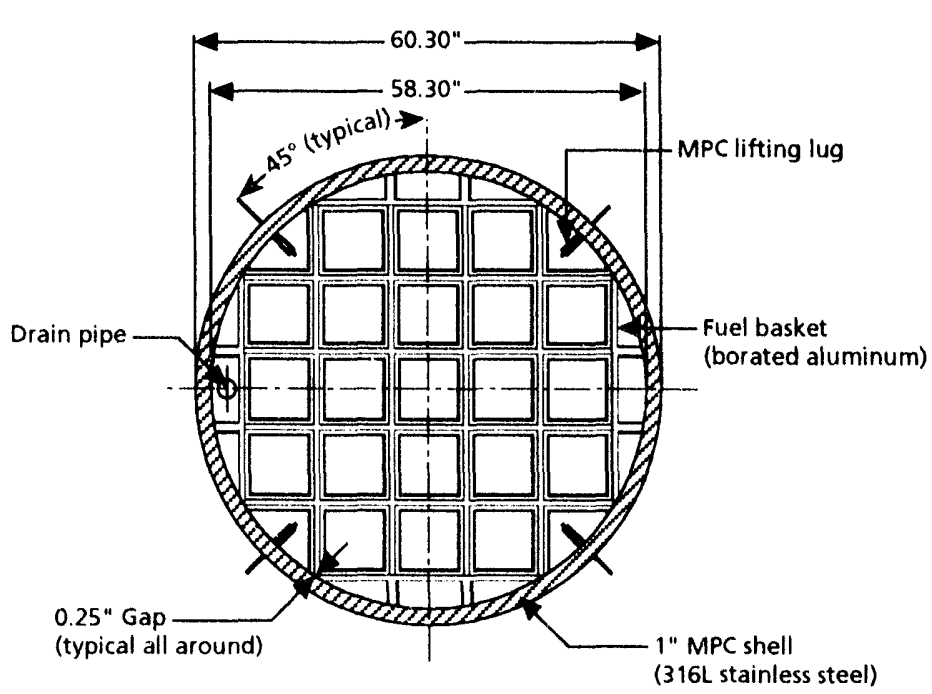

Figure 9. Cross section of a large (125-ton) multipurpose canister. during transportation, where the containment boundary is provided by the transportation cask. The shield plug provides shielding from radiation to protect workers during welding.

\section{Factors affecting multipurpose-canister designs and choices of materials}

Among the principal factors affecting the design of the multipurpose canister is the requirement for high structural strength to withstand hypothetical accident scenarios postulated in Nuclear Regulatory Commission regulations for transportation (10 CFR Part 71), including a 30-foot drop onto an unyielding surface. The multipurpose canister, contained inside the transportation cask, is to remain intact under these hypothetical conditions, and the fuel basket, which provides criticality control, is not permitted to yield. This requirement is met through the use of relatively thick tube walls made of type 316L stainless steel: the walls of the shell are 1 inch thick for the large multipurpose canisters and $7 / 8$ inch thick for the medium canister's.

The multipurpose canisters must also meet a regulatory requirement for storage: the temperature of the fuel cladding inside the canister may not exceed $340^{\circ} \mathrm{C}$. This requirement is met by including aluminum sheets in the fuel basket to enhance thermal conductivity. The composite metal tubes that form the basket are 0.25 inch thick. 
Another requirement, also specified in the Commission's regulations for transportation, is the use of neutron absorbers to prevent criticality. This requirement is met by using a borated-aluminum alloy for the aluminum heat-conductor sheets in the fuel basket. The borated aluminum provides for an even dispersion of boron-10, a neutron absorber. The borated aluminum is clad with a stainless-steel outer covering to protect it and to maintain the position of the aluminum sheets under accident conditions.

For the inner lid, plates 2.5 and 2 inches thick were found to be sufficient for the large and medium multipurpose canisters, respectively. The thicknesses determined to be adequate for the outer lid were 2.75 inches for the large canister and 2.5 inches for the medium canister.

For evaluation purposes, the shield plug of the multipurpose canister was considered to be made of depleted uranium. The plug serves to protect welders and inspectors from radiation. By using remotely controlled welding with a semiautomatic welding machine much of the potential radiation exposure of welders can be avoided. However, weld inspections and any required repair work may result in higher worker exposures to radiation.

\section{Design of transportation casks}

Two conceptual designs for transportation casks were prepared, one for the large canisters and the other for the medium canisters. The approach was to design structurally strong and efficiently shielded casks with conservative design margins. The casks are designed to withstand the accident conditions specified in the regulations, including a 30-foo, ide drop onto an unyielding surface and a drop onto a 40 -inch steel pin (the puncture test).

The outer and inner walls of the cask are made of stainless steel. They enclose depleted uranium and a layer of lead to provide shielding from gamma radiation. This shielding is very efficient, yielding calculated dose rates well below regulatory limits at all locations. Furthermore, the use of both materials facilitates fabrication.

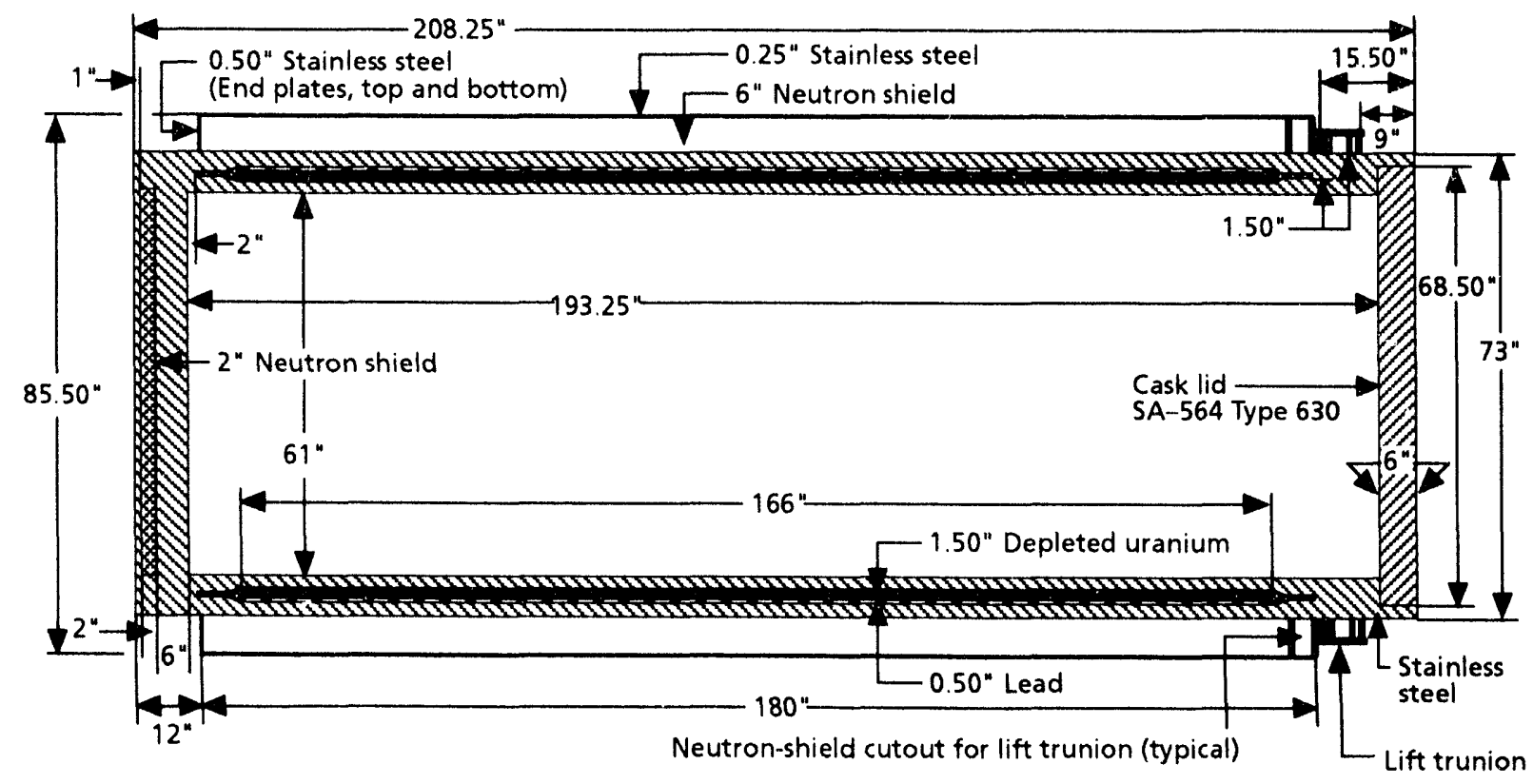

Figure 10. Dimensions of the transportation cask for a large multipurpose canister. 


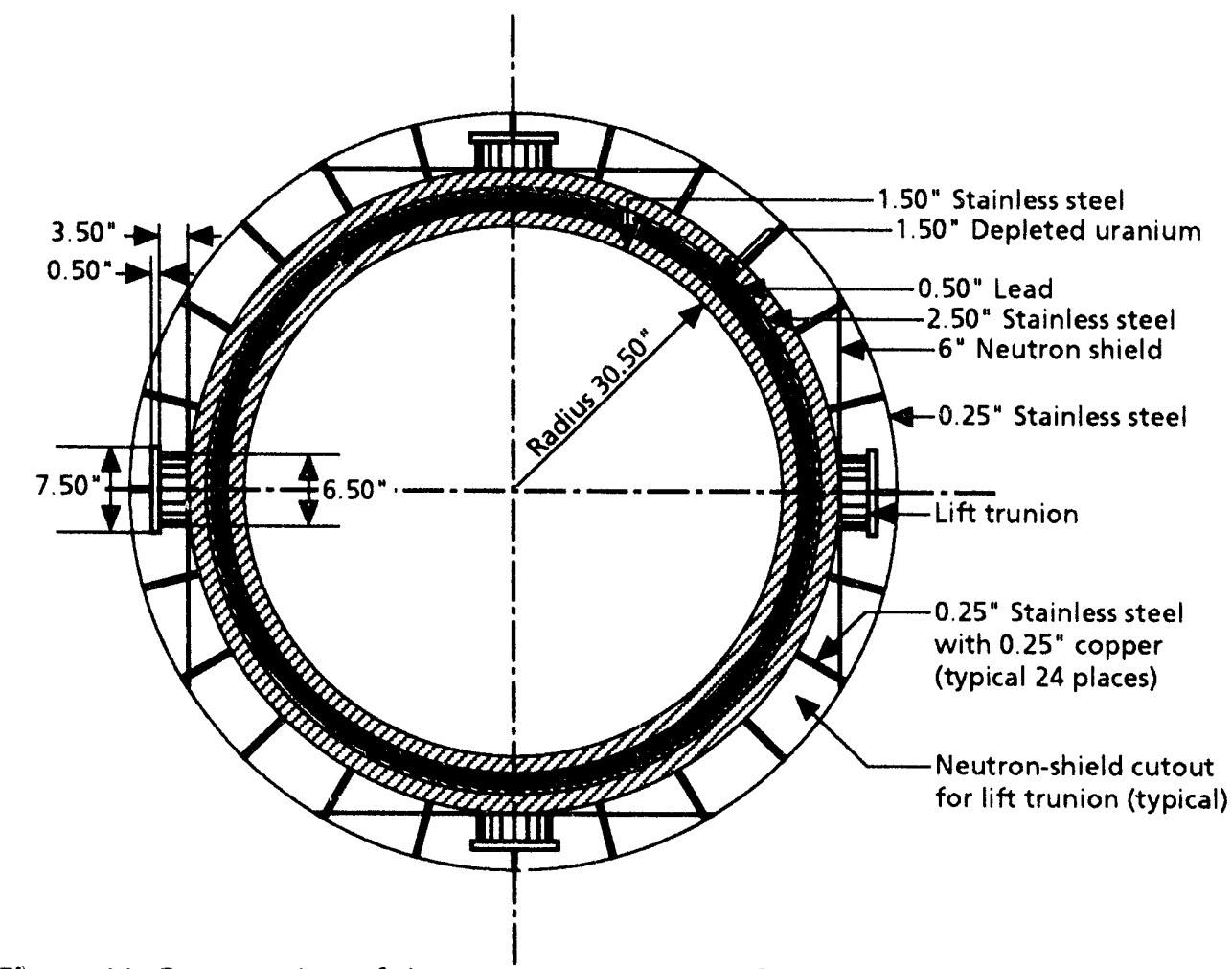

Figure 11. Cross section of the transportation cask for a large multipurpose canister.

The transportation cask is designed for a maximum fuel-cladding temperature of less than $340^{\circ} \mathrm{C}$. This temperature is low enough to meet regulatory requirements for storage. Figures 10 and 11 show design details for the transportation cask intended for large canisters.

\section{LICENSING}

No part of the multipurpose-canister system can be used without licenses from the Nuclear Regulatory Commission. In order to obtain these licenses, or certificates of compliance, it will be necessary to demonstrate compliance with four sets of regulations. The licensing effort will involve the utilities, for at-reactor storage and the cask-to-cask transfer of spent fuel; the vendors of transportation casks and multipurpose canisters; and the Department of Energy for the MRS facility and the repository.

\section{At-reactor storage}

The use of multipurpose canisters at a reactor site is covered by two regulations: 10 CFR Part 50, "The Licensing of Production and Utilization Facilities," and 10 CFR Part 72, "Licensing Requirements for the Independent Storage of Spent Nuclear Fuel and High-Level Radioactive Waste."

Activities inside or at the spent-fuel pool, such as spent-fuel loading into multipurpose canisters, transfer casks, or transportation casks, are regulated by 10 CFR Part 50 . The utility must perform a safety evaluation as prescribed by the regulation. The issues of concern are related to the handling of heavy loads and the ability of cranes and structures to handle the heavy loads safely.

The storage of multipurpose canisters at the reactor site will require a license under 10 CFR Part 72. The activities authorized by 10 CFR Part 72 include not only possession and storage; they also include the transfer of spent fuel from the storage pool. A Part 72 license can be specific to the site, in which case the utility submits an application to the Commission and goes through a formal licensing process. 
A more likely alternative, however, is the general license, which is obtained by a process similar to that used for transportation casks: the vendor of the multipurpose-canister storage system submits a topical safety analysis report to the Commission and requests a certificate of compliance. If the Commission approves and issues the certificate, the storage system is listed in 10 CFR 72.214, and any utility holding a reactor operating license may use the storage system after an internal safety evaluation has been completed and the staff of the Commission has verified that there are no unreviewed safety questions.

\section{Cask-to-cask transfer}

As already mentioned, 19 facilities at which spent fuel is stored will not be able to use multipurpose canisters because they do not have the facilities and equipment for loading multipurpose canisters inside the spent-fuel pool. However, at these facil ties it may be possible to use a cask-to-cask transfer system that would allow multipurpose canisters to be loaded outside the pool. The Department of Energy and Electric Power Research Institute have entered into a cooperative agreement to develop a detailed design of a cask-to-cask transfer system for spent-fuel assemblies. The licensability of the system will also be evaluated.

\section{Transportation}

The multipurpose-canister transportation system, including the canister and its overpack, must be certified by the Nuclear Regulatory Commission under 10 CFR Part 71, "Packaging and Transportation of Radioactive Materials." The design requirements of these regulations are more demanding than the regulatory requirements for storage. The most stringent requirement is the need to demonstrate that the multipurpose-canister transportation system can withstand the hypothetical accident conditions postulated in 10 CFR Part 71 without losing its integrity or releasing radioactive material. These requirements were the driving factors in the design of the canisters and their fuel baskets.

\section{The MRS facility}

The MRS facility will be licensed in accordance with 10 CFR Part 72. Under current operating assumptions - that is, an MRS facility that receives both multipurpose canisters and spent-fuel assemblies the use of multipurpose canisters is not expected to affect licensing.

\section{Repository}

The repository will be licensed in accordance with 10 CFR Part 60, "Disposal of High-Level Radioactive Wastes in Geologic Repositories." These regulations specify requirements for the surface facilities and operations of the repository, underground facilities and operations, the "waste package," and long-term performance. The waste package is the engineered barrier to the release of radionuclides. It consists of the waste, the outer disposal container, and any internal container that might be used, such as the multipurpose canister.

The licensing issues related to the use of multipurpose canisters for disposal include the heat loading of the repository, the long-term control of nuclear criticality, and requirements for shielding. Regulatory guidance for the resolution of these issues is expected during the licensing of the storage and transportation systems. 


\section{Licensing strategy}

The licensing of the multipurpose canisters and their overpacks under 10 CFR Parts 71, 72, and 60 will be a complex process involving technical issues that have not been previously addressed by the Nuclear Regulatory Commission for any single system. Furthermore, different branches of the Commission's staff are responsible for the different regulations. To ensure that the licensing can be accomplished on time, the Department of Energy intends to pursue the resolution of technical issues before the formal licensing process begins. This will involve interactions with the Commission's staff to establish a common understanding of regulations and to define the technical information that is necessary to demonstrate compliance. Such a process has been successfully used for the repository project.

\section{COMPLIANCE WITH ENVIRONMENTAL REGULATIONS}

The Department of Energy will prepare an environmental assessment for the multipurpose canisters before submitting applications for certificates of compliance for transportation and storage to the Nuclear Regulatory Commission. If this assessment indicates that significant environmental effects could result, then the Department will have to analyze and evaluate them in accordance with the requirements of the National Environmental Policy Act.

For disposal, the use of multipurpose canisters as part of the waste package will be addressed in the environmental impact statement that will be prepared for the repository.

\section{SCHEDULE}

If the Department decides to use multipurpose canisters and the request for proposals is issued in March 1994, the first canister should be available for use at a reactor site in January 1998. The first transportation cask for transporting multipurpose canisters to the MRS facility should be ready in January 2000. The contemplated major milestones in the schedule for canister and transportation-cask development are shown in Figure 12.

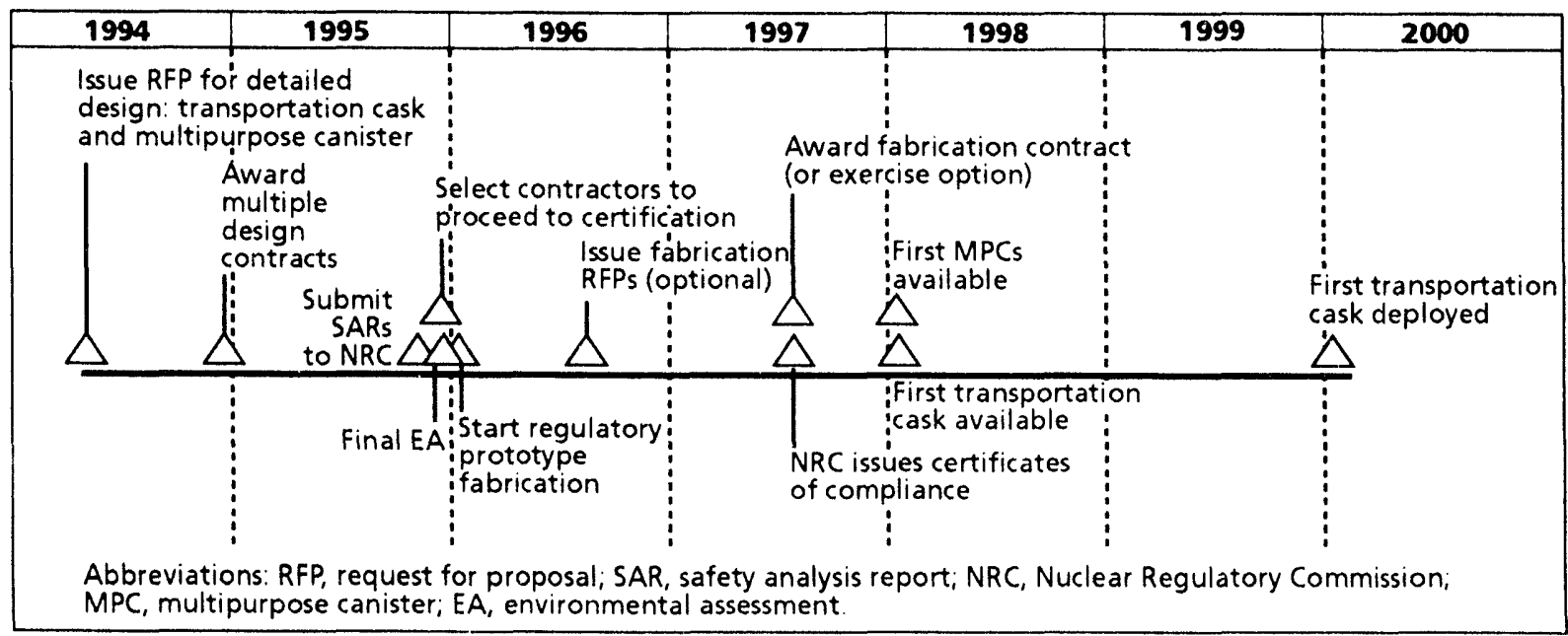

Figure 12. Schedule for the multipurpose canisters and their transportation casks. 
January 2000 is also the date at which the MRS facility is expected to start operations. The contemplated schedule for this facility, shown in Figure 13, depends on recommending an MRS site to the Congress in September

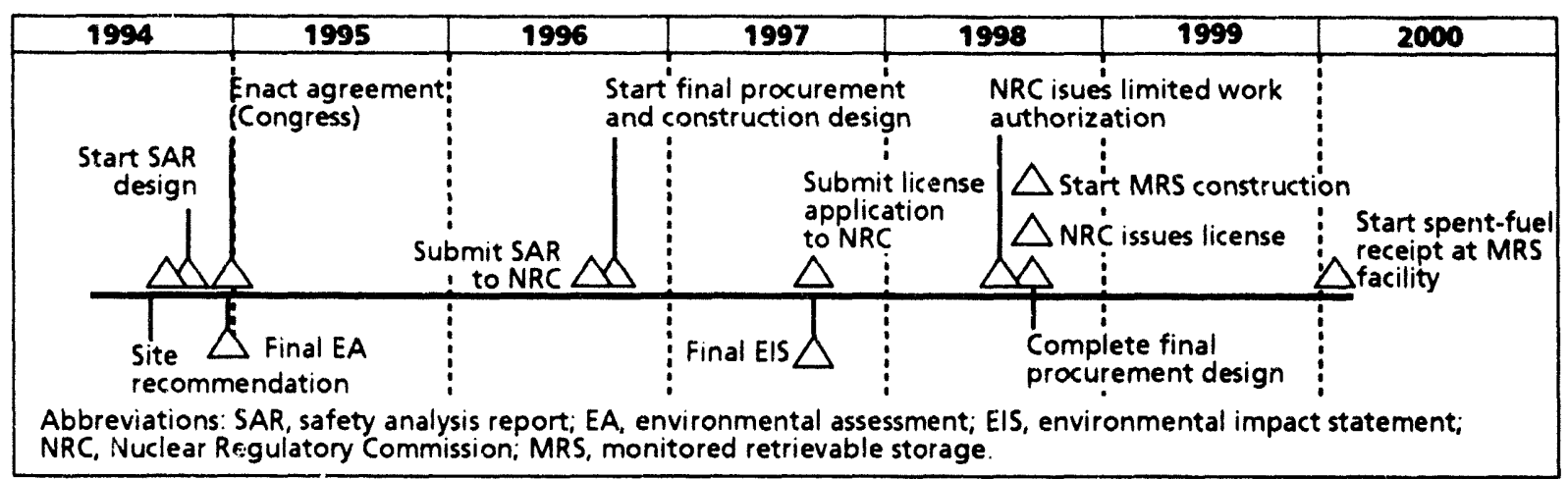

Figure 13. Schedule for the MRS facility.

\section{Costs}

A multipurpose canister will cost more than a canister designed for storage only. Its cost depends largely on two factors. One is the high structural strength needed to meet the transportation-accident conditions postulated in 10 CFR Part 71. Another factor is the use - in canisters intended for fuel from pressurized-water reactors - of borated aluminum to enhance heat conduction and prevent nuclear criticality.

The cost of the multipurpose canister is offset by savings in other parts of the waste-management system. At the MRS facility, for example, only one transfer cell (the costliest component of the facility) is needed instead of three, and personnel requirements are significantly reduced: instead of the 540 to 740 workers estimated in previous cost analyses for an MRS facility without multipurpose canisters, the MRS facility in the multipurpose-canister system would need only 430 to 450 workers. Similarly, the use of multipurpose canisters at the repository would facilitate and expedite waste-handling operations, with savings in design and construction costs as well as operating costs.

Preliminary estimates of the costs for the four types of canisters discussed here are as follows:

$\begin{array}{cr}\begin{array}{c}\text { Type of multipurpose canister } \\ \text { Large (125-ton) }\end{array} & \text { Cost per multipurpose } \\ 21 \text { PWR assemblies } & \$ 354,000 \\ 40 \text { BWR assemblies } & \$ 432,000 \\ \text { Medium (75-ton) } & \\ 12 \text { PWR assemblies } & \$ 287,000 \\ 24 \text { BWR assemblies } & \$ 276,000\end{array}$

The abbreviations "PWR" and "BWR" stand for pressurized-water reactor and boiling-water reactor, respectively. 


\section{INVOLVEMENT OF STAKEHOLDERS}

The Department of Energy is firmly committed to involving stakeholders - that is, potentially affected and interested parties - in major decisions. In the case of the multipurpose canister, the primary stakeholders are the utilities since they would be directly involved in implementing the multipurposecanister system. Other stakeholders are potential volunteer hosts for the MRS facility, potentially affected State and local governments, State legislators, public interest groups, manufacturers of equipment (multipurpose canisters, transportation casks), industry and utility organizations, regulators, and public utility commissioners.

To provide a mechanism for effective two-way communication with stakeholders during the conceptual design phase, the Department has held two workshops. The first, held on July 1-2, 1993, focused on identifying multipurpose-canister-related issues of concern to the stakeholders. Three recommendations emerged from the workshop discussions:

1. The design of the multipurpose canister should be driven by storage and transportation requirements, not by the repository, and the Department should focus on near-term utility and transportation requirements.

2. Cost should be a major consideration in multipurpose-canister design, manufacturing, and material selection.

3. Stakeholder involvement should be continued to enhance public acceptance of the wastemanagement program.

At the second workshop, held on November 17-18, 1993, the Department discussed the conceptual design report and heard opinions about implementing the multipurpose-canister system. The Department intends to seek advice on how best to continue, and broaden, the involvement of stakeholders. 


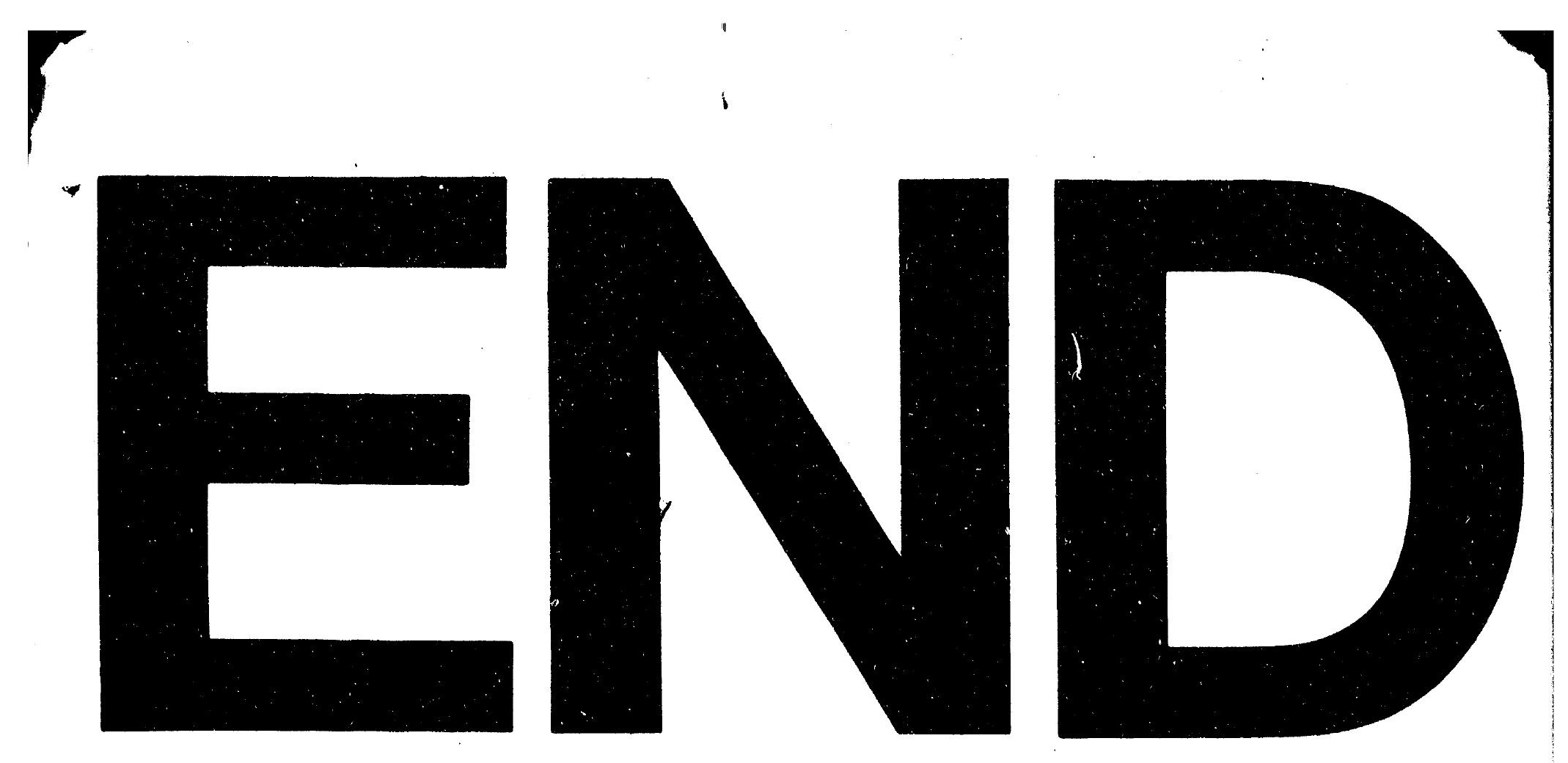


